\title{
Ecological Restoration of Gullies and Stream Channels
}

\section{Understanding the type of soils and vegetation on top of streambanks can help initiate restoration along streams.}

\author{
By John Murray
}

$\mathrm{F}$ or years natural resource managers have tried to heal gullies and downcast stream channels with rock checks, dams, hay bales, and other silt catching structures. Beavers are nature's engineers, and they help, but they need existing water tables and running water to work. Most of these efforts are not very successful or cost-effective. So, how do we deal with an eroding gully, the loss of water table and ever widening stream channels?

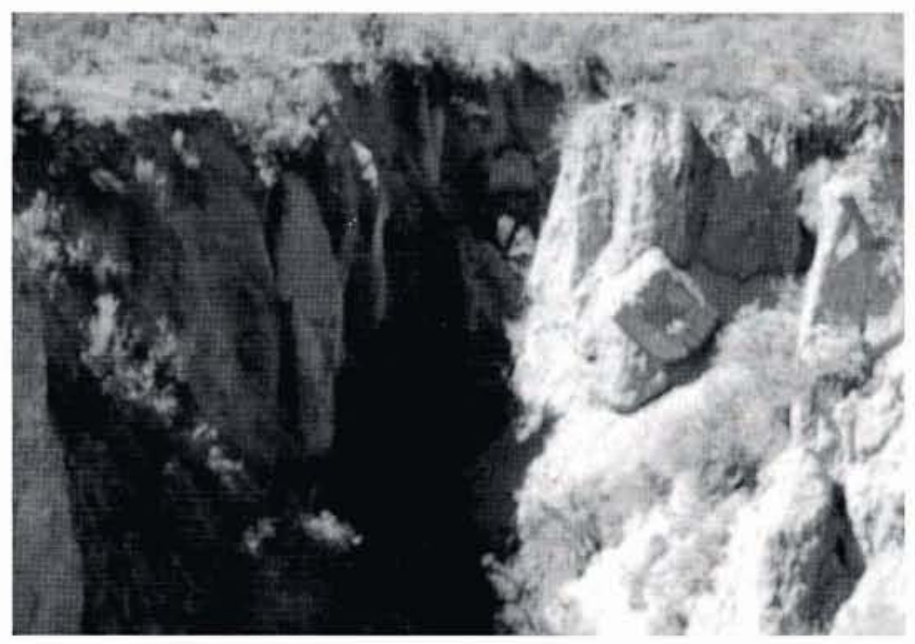

Before Gully

We've all seen straight up and down banks. How do they get this way and why do they perpetuate themselves? First, we need to understand the processes involved in erosion. The conventional wisdom holds that once a gully or stream downcuts, it starts to widen and form secondary benches and floodplains. This doesn't have to happen.

The process of channel widening is directly relat- ed to the type of vegetation on top of the banks. Shrubs such as big sagebrush are extremely deeprooted. This allows them to use moisture deep into the soil profile. Basin big sagebrush - Artemisia tridentata tridentata, Wyoming big sagebrush Artemisia tridentata wyomingensis and mountain big sagebrush - Artemisia tridentata vaseyana all have a shallow fiberous root system plus a deep taproot. This enables these shrubs to dry the soil out deep into the profile. This process does not apply to willows or other desirable riparian shrubs, but rather upland shrubs that move into the riparian zone. This is a very important concept as this determines the stability of the bank.

Water flowing in the channel undercuts the bank. With the bank undercut and dry soil to the top of the bank, it becomes too heavy to hold it up. As the soil dries, cracks form on top - Figure 1. This al-

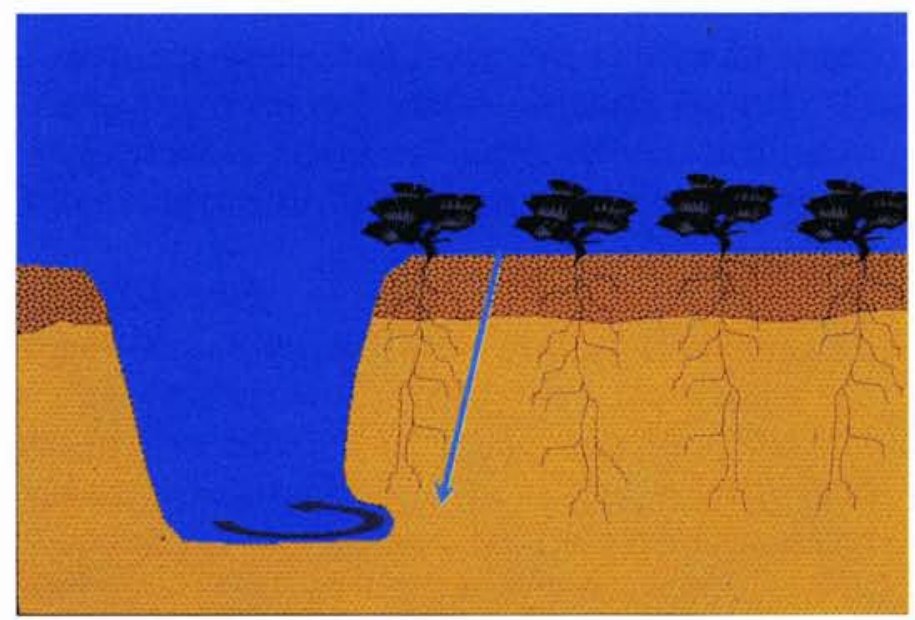

Figure 1. 
lows moisture to enter and the cracks become bigger. The result is that the bank falls off as a vertical slab - Figure 2. The process starts all over again

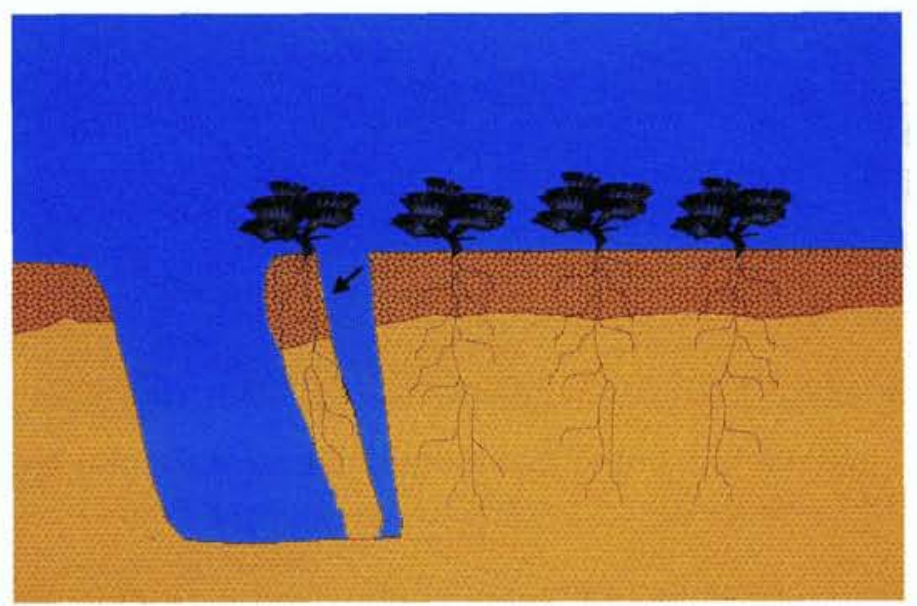

Figure 2.

with the water undercutting the bank and eventually falling away. The channel continues to widen Figure 3.

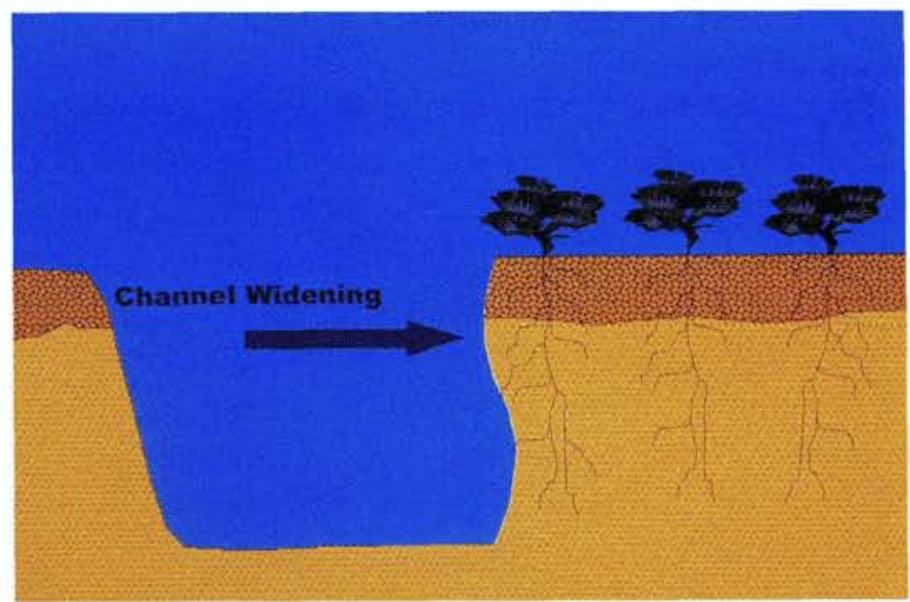

Figure 3.

What would happen if the deep tap-rooted species were replaced with a shallower, fibrous root system? Would the bank act the same? If grasses occupy the top of the bank, the grasses will actually absorb and hold the moisture either from snow melt or rain - Figure 4. As the soil absorbs more and more moisture it becomes super saturated and if it continues will actually liquefy and flow. This is a very powerful and natural occurrence of certain soils.

The difference is that when the bank is undercut, the top does not break off but rather slumps to the

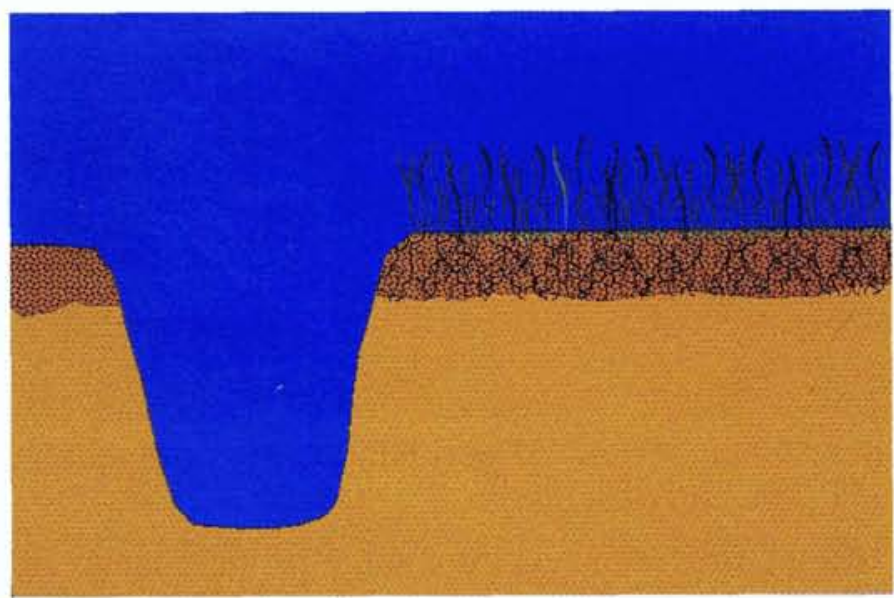

Figure 4.

bottom of the channel - Figure 5. This slumping causes small dams and checks to form which in turn slows the flow of water and builds silt behind

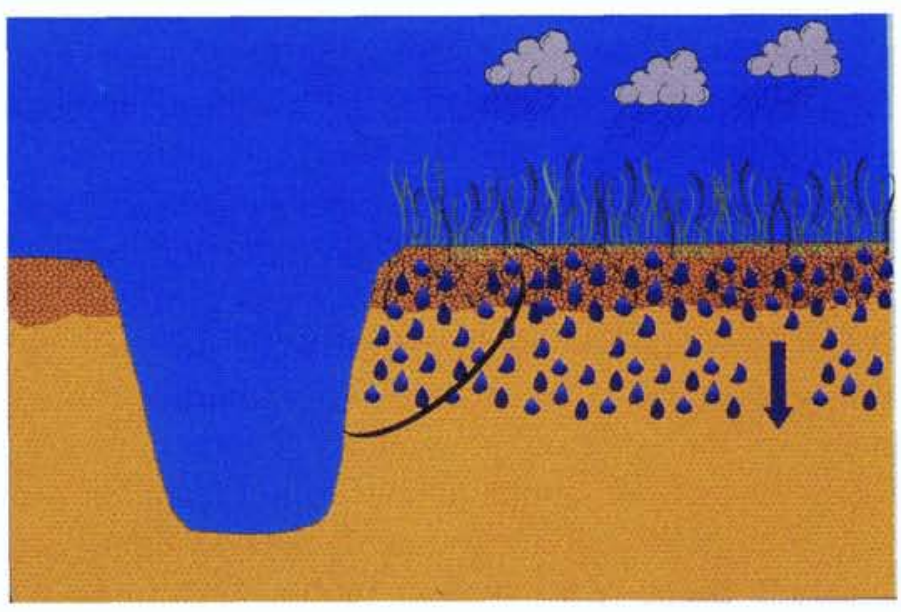

Figure 5

them. The grasses now occupy the bottom of the downcuts and also the sides, thus eliminating the ability of the channel to continue widening - Figure 6. The channel is now confined and the banks are stable. Slope, and gradient of the channel is not a factor in the ability of a system to heal its banks. The factors are the vegetation, soils, water, and the slope of the bank. 


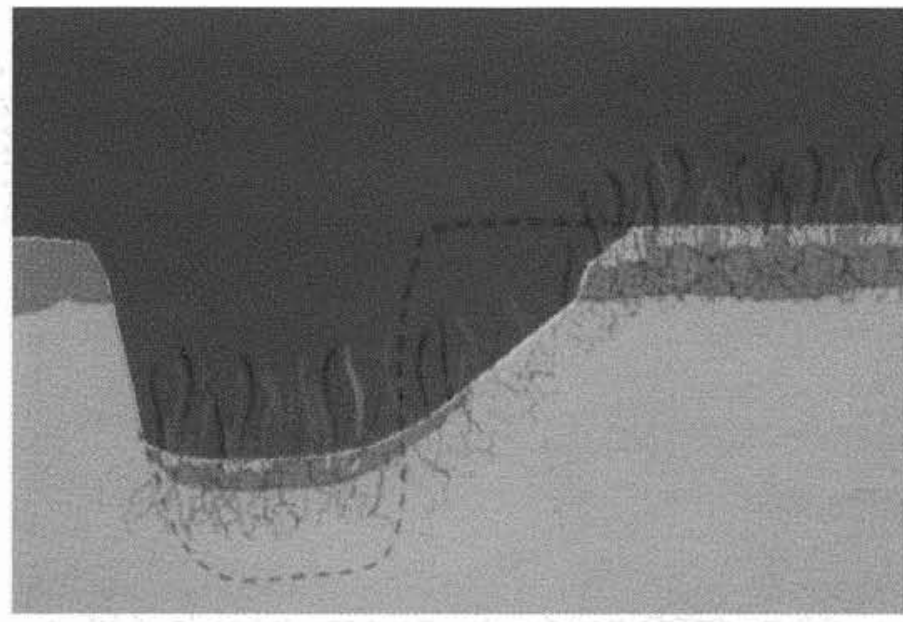

Figure 6.

Not all soils will react the same to the change in vegetation. In order for soils to slump or slide they must have certain characteristics. At present, these characteristics have been identified as;

a) clay over sandstone,

b) soils over impermeable or slowly permeable soils,

c) clays over texture breaks,

d) or any situation where water hits a soil texture change and spreads laterally.

There may be others but they haven't been identified at this time.

Water is a factor in that there needs to be enough to super saturate the soil. It may take a length of time before the soil absorbs enough moisture to slump. Soils in low precipitation areas do have the ability to slump, if there are enough fiborous rooted plants on the edge of the bank to absorb moisture. Bare soil will not slump, as absorption rates are not fast enough or good enough to take in adequate moisture. Slope of the bank is another factor to consider. Naturally, the steeper the bank, the more susceptible it is to slumping.

\section{Initiating Restoration}

How do we create the conditions to initiate the restoration process? This slumping process can happen naturally when a natural event changes the structure of the stream bank vegetation. Wildfires and mortality from insects are two primary natural causes of altering woody vegetation. Land managers can also influence this process by using prescribed fire, herbicides and mechanical brush treat-

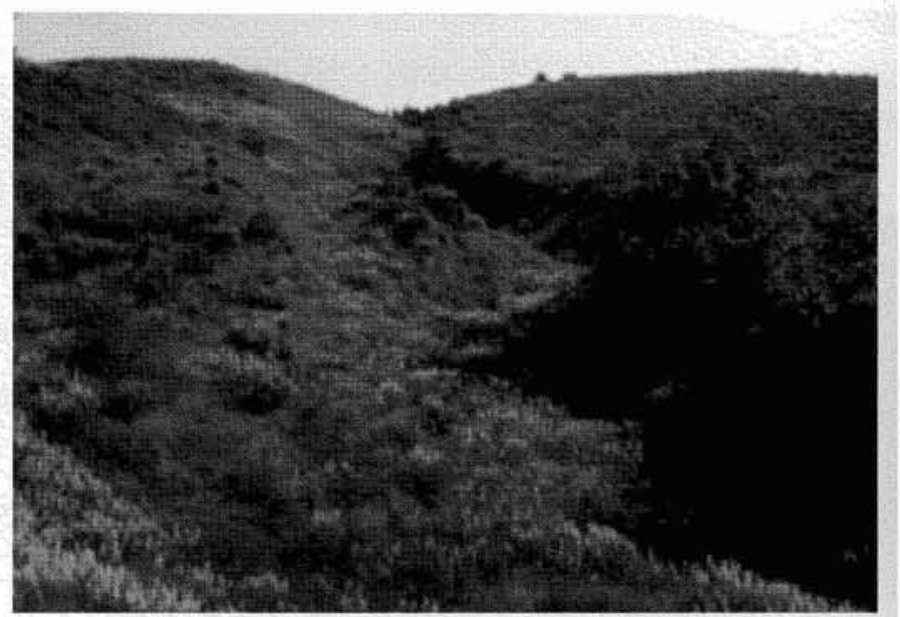

Left side was treated and slumped. The right side was left untreated.

ments. Grazing systems that allow for a good flush of grass growth are essential for the process to work.

However, there's always a "but" involved in anything new, and there are some downsides. The first is not being able to predict when the banks will slump. We can only give it the opportunity and expect that it will happen. Previous experience has indicated that it should happen within a couple of years or sooner.

The second downside is that this will not happen in all soils, even if we give them the opportunity. They just don't possess the characteristics mentioned earlier to slump. Different approaches need to be researched for these cases.

Also, the width of the brush manipulation on top of the bank is not certain. The standard used to date is at least a one to one balance. An example would be if a gully is 10 feet deep then it should be treated 10 feet back from the edge.

\section{References}

Stuges, David L., 1977. Soil Moisture Response to Spraying Big Sagebrush: A seven-year study and literature interpretation. USDA Forest Service Research Paper. RM-188, 12p. Rocky Mt. For and Range Exp. Stn., Fort Collins, Colorado, 80521

Author: John E. Murray is a Range Conservationist with the NRCS located at 102 Par Place, Montrose, Colorado 81401. He can be reached by phone at (970) 249-8407 or by email at john.murray@co.usda.gov 